Historic, Archive Document

Do not assume content reflects current scientific knowledge, policies, or practices. 

FARM CREDIT ADMINISTRATION

UNITED STATES DEPARTMENT OF AGRICULTURE

WASHINGTON, D.C.

\section{THE STATUS OF COOPERATIVES \\ IN}

FRUIT AND VEGETABLE CANNING

1943 AND 1944

By

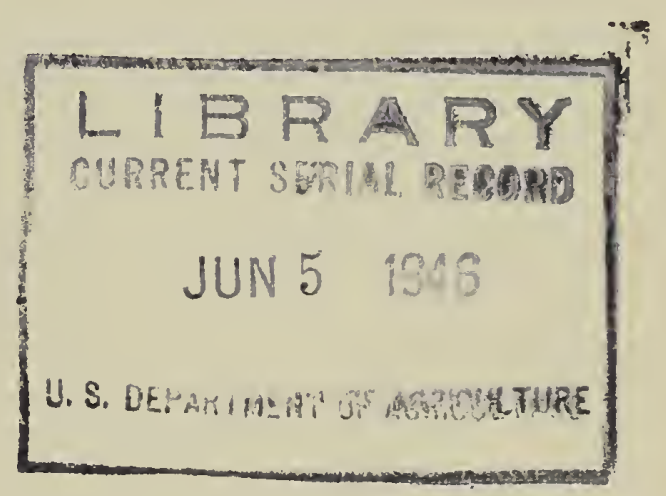

G. M. WEBER

COOPERATIVE RESEARCH AND SERVICE DIVISION 


\section{UNITED STATES DEPARTMENT OF AGRICULTURE \\ FARM CREDIT ADMINISTRATION \\ WASHINGTON 25, D. C. \\ I. W. OUGGAN, GOVERMOR}

COOPERATIVE RESEARCH AND SERVICE DIVISION

HAROLD HEDGES. CHIEF

\section{CONTENTS}

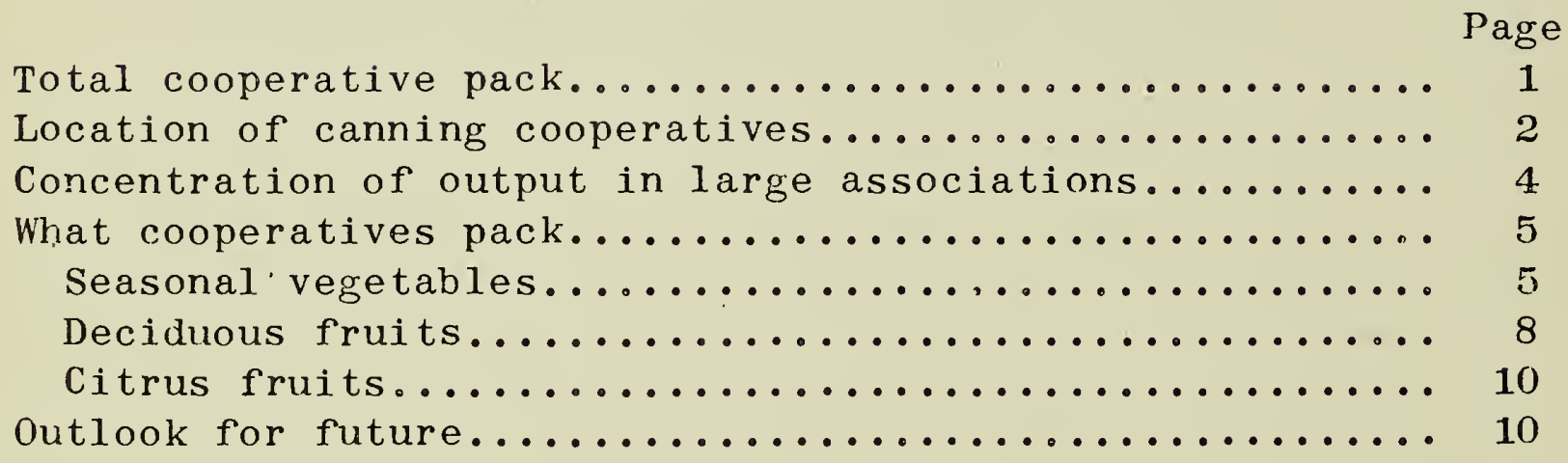

The Cooperative Research and Service Division conducts research studies and service activities relating to problems of management, organization, policies, merchandising, sales, costs, competition, and membership arising in connection with the cooperative marketing of agricultural products and the cooperative purchase of farm supplies and services; puhlishes the results of such studies; confers and advises with officials of farmers' cooperative associations; and cooperates with educational agencies, cooperative associations, and others in the dissemination of information relating to cooperative principles and practices.

COPIES OF THIS PUBLICATIOH MAY BE HAD ON REQUEST

While a supply is aVallable from the

OIRECTOR OF INFORMATION AND EXTENSION

FARM CREDIT ADMINISTRATION

U.S. OEPARTMENT OF AGRICULTURE

WASHINGTON 25,0 . C. 


\title{
THE STATUS OF COOPERATIVES IN FRUIT AND VEGETABLE CANNING
}

\section{AND 1944}

\author{
by \\ G. M. Weber
}

Senior Agricultural Economist

Comprehensive data on the quantities of fresh seasonal vegetables and fruits canned by farmers' cooperatives in 1943 and 1944 are now available for the first time in information supplied to the Government in connection with its wartime food program. The source data were reports of operations submitted by all cooperative organizations in the United States engaged in canning these products, except several small associations that either did not can in these 2 years or failed to report. of the latter, the output would constitute probably less than 1 percent of the cooperative total. These production records form the primary basis for this study.

From these reports it is possible to answer a number of questions previously unanswered regarding cooperative fruit and vegetable canning. They provide information on the volume of output of the cooperative canneries, on the place of cooperative canners in the canning industry of the country as a whole, on, the kinds of fruits and vegetables canned, and the relative importance of each. Such information is useful both in an appraisal of the current picture with respect to cooperative canners of fruits and vegetables and in providing a basis for the consideration of postwar problems and prospects for cooperative canners.

While the data for 1943 and 1944 are important in their own right, their usefulness is limited by the fact that comparable statistical data for earlier years are not available. The earlier picture at best is sketchy. Information for certain other years on the number of associations engaged in canning is available. There are also annual data on the total value of sales by cooperatives of all fruits and vegetables combined, both fresh and processed together. But comprehensive data on the output of cooperative canners, either in the aggregate or in terms of the several products packed, have not been reported previously. 1

\section{TOTAL COOPERATIVE PACK}

The total annual pack of seasonal vegetables by farmer cooperative canners was more than 5 million cases (basis, 24 No. 2 cans) in each of the 2 years 1943 and 1944. This quanti-ty, which constituted somewhat more than 3 percent of the national total, represents the output of 47 cooperative organizations.

${ }^{1}$ A general statement that about 5 percent of the total value of canned frults and vegetables, excluding soups, in the United States appears in an FCA publication. See Fogelberg, N., and Le1th, G. W., "Cooperative Canning of Frults and Vegetables." F. C. A. Bul. 47, 78 pp., 11ius. 1941. 
In deciduous fruits and berries, excluding pineapples, cranberrjes, prunes, grapes, and figs, the cooperative pack in these 2 years averaged yearly almost $2 \frac{7}{2}$ million cases (basis, 24 No。2 $\frac{1}{2}$ cans), representing about 6 percent in 1943 and over 7 percent in 1944 of the output of the whole country. Plants of 21 associations contributed to these cooperative packs.

Farmer cooperatives are much stronger in the citrus canning field, with the total pack of the 13 associations reaching 11 million cases (basis, 24 No. 2 cans) of single strength juice and segments, or about 27 percent of the national total, during the season 1943-44.

\section{LOCATION OF CANNING COOPERATIVES}

Cooperative associations canning fruits and vegetables in 1944 were distributed among 23 States, widely scattered geographically. The distribution of these canneries among the states was as follows: ${ }^{2}$

$\begin{array}{llllll}\text { Maine } & 2 & \text { Indiana } & \mathbf{4} & \text { Nebraska } & 3 \\ \text { New York } & 4 & \text { Michigan } & 2 & \text { Arkansas } & 3 \\ \text { Pennsylvania } & 2 & \text { Minnesota } & 3 & \text { California } & 5 \\ \text { Maryland } & 2 & \text { Wisconsin } & 2 & \text { Oregon } & 9 \\ \text { Virginia } & 6 & \text { Iowa } & 2 & \text { Washington } & 2 \\ \text { Florida } & 8 & \text { Missouri } & 2 & \text { Other } & 6^{3}\end{array}$

Oregon and Florida are the leading States in number of cooperative canning associations with 9 and 8, respectively. Virginia follows with 6 and California with 5, with New York and Indiana having 4 each.

The number of cooperatives canning seasonal vegetables and the number canning deciduous fruits in each State in 1944 are shown in table $\mathbf{1}$, along with the percentage contributed by cooperative plants in each State to the national cooperative pack during the 2 years 1943 and 1944 . Associations canning both fruits and vegetables are listed in this table under each category, so that the total number of associations involved is smaller than the sum of the numbers in the two columns.

This table emphasizes the concentration of the output of both seasonal vegetables and deciduous fruits on the Pacific coast. The three Pacific Coast States together supplied almost 90 percent of the deciduous fruits canned by cooperatives in the United States and about 56 percent of the seasonal vegetables. Among Oregon's cooperatives, those packing seasonal vegetables represented 42 percent of the cooperative total, and those packing deciduous fruits over 20 percent of that total. Cali-. fornia cooperatives furnished nearly 54 percent of all cooperatively canned deciduous fruits and somewhat more than 9 percent of the seasonal vegetables. Cooperatives in Michigan and Wisconsin canning mainly

${ }^{2}$ Associations having more than one canning plant are counted only once except where the plants are located in more than one State. The numbers shown do not include plants canning grapes or grape Juice, olives, figs, cranberrles, okra, baked beans, or sauerkraut, because data on production of these products were not made avaliable for 1944.

" "other" includes one each in North Carolina, Colorado, Idaho, Wyoming, Arizona, and Texas. 
Table 1. - Number of cooperatives canning seasonal vegetables and deciduous fruits and berries in 1944 and annual average percentage of total volume of cooperative pack for 1943 and 1944, by principal States

(Case basis: 24 No. 2 cans for vegetables, 24 No. $2 \frac{1}{2}$ cans for fruits)

\begin{tabular}{|c|c|c|c|c|}
\hline \multirow[b]{2}{*}{ State } & \multicolumn{2}{|c|}{ Seasonal vegetables } & \multicolumn{2}{|c|}{ Deciduous fruitsa } \\
\hline & $\begin{array}{c}\text { Associations } \\
\text { reporting } \\
\text { in } 1944\end{array}$ & $\begin{array}{l}\text { Cooperative } \\
\text { pack } \\
1943 \text { and } 1944\end{array}$ & $\begin{array}{c}\text { Associations } \\
\text { reporting } \\
\text { in } 1944 \\
\end{array}$ & $\begin{array}{c}\text { Cooperative } \\
\text { pack } \\
1943 \text { and } 1944\end{array}$ \\
\hline & Number & Percent & Number & Percent \\
\hline oregon............... & 6 & 42.0 & 6 & 20.3 \\
\hline Cal1 forn1a............ & 2 & 9.4 & 2 & 53.8 \\
\hline New York.............. & 4 & 9.4 & 2 & 0.3 \\
\hline Minnesota............. & 3 & 8.4 & - & - \\
\hline Pennsylvania.......... & 2 & 5.6 & 1 & 0.4 \\
\hline Washington........... & 1 & 4.3 & 2 & 14.4 \\
\hline Maryland.............. & 2 & 3.0 & 1 & (b) \\
\hline Arkansas............... & 3 & 2.6 & - & - \\
\hline 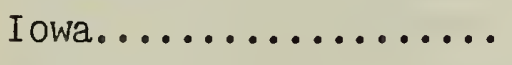 & 2 & 2.2 & - & - \\
\hline Michigan............. & 1 & 1.8 & 2 & 6.0 \\
\hline Nebraska............. & 3 & 1.7 & - & - \\
\hline Colorado............... & 1 & 1.6 & 1 & 0.3 \\
\hline Idaho................ & 1 & 1.6 & - & - \\
\hline Wisconsin............. & 1 & 1.5 & 1 & 3.5 \\
\hline Virginia............. & 6 & 1.4 & 1 & (b) \\
\hline Indiana.............. & 4 & 1.3 & - & - \\
\hline North Carolina......... & 1 & 1.2 & - & $-\cdot$ \\
\hline All other states ${ }^{c} \ldots .$. & 4 & 1.0 & 2 & 1.0 \\
\hline Total............ & 47 & 100.0 & 21 & 100.0 \\
\hline
\end{tabular}

${ }_{b}^{a}$ Not included are grapes, pineapples, plums, prunes, and cranberries:

Less than 0.1 percent.

cIncludes for vegetables Maine 1, Missouri 2, Wyoming 1; for fruits, Maine 2.

Source of data: Original reports to the Farm Credit Administration and other Federal agencies.

cherries were the only additional ones to contribute appreciably to the total cooperative output of deciduous fruits. However, seasonal vegetable cooperatives located in New York, Minnesota, and Pennsylvania together turned out nearly 25 percent of the total cooperative pack.

This concentration on the Pacific coast of cooperative canning of deciduous fruits parallels a similar concentration in that area of privately operated canneries. In 1944, California alone accounted for well over half of the deciduous rruit pack in continental United States and the three states combined furnished nearly three-fourths of that total. In seasonal vegetables, on the other hand, the private canning industry is relatively more important in the Middle West and Atlantic Seaboard States, the three Pacific Coast states together providing only about 20 percent of the total pack in 1944. ${ }^{4}$

${ }^{4}$ Based on "Western Canner and Packer, 1945 Statistical Review and Yearbook, " D. 94, and "Canned Food Pack Statistics: 1944," of the National Canners Association. The percentages given here were obtained by excluding fruit juices, pineapples, and ligs from the deciduous fruit totals, and artichokes, soups, tomato products other than Juice, and miscellaneous vegetable specialties from the seasonal vegetable totals. 
In the canning of single-strength citrus juice, Florida plants predominate with about three-fourths of the national total, thus paralleling the relative position of this state among citrus cooperative canners.

Oregon outranks all other states in the relative importance of cooperative canneries compared with those privately operated. In 1943 and 1944 well over one-third of the state's pack of seasonal vegetables and about one-half of the state's green snap beans and beets were canned by cooperatives. They canned also about 15 percent of Oregon's total pack of deciduous fruits. Al though California cooperative canners packed over half of all cooperatively canned deciduous fruits, their output comprised only about 5 percent of the state!s total of such fruit, a fact explained by the dominant position of California in the industry.

\section{CONCENTRATION OF OUTPUT IN LARGE ASSOCIATIONS}

To a considerable extent the geographic concentration in terms of volume of output reflects the fact that canning by cooperatives, like that by privately operated establishments, is dominated by a comparatively small number of large organizations. This domination is evident in the production data for 1943 and 1944. However, the relative importance of several of the larger organizations was probably exaggerated during these war years owing to large Government contracts and their ability to draw material from considerable distances.

of the 54 cooperatives canning deciduous fruits, seasonal vegetables, or both in 1944, 5 associations all on the Pacific coast accounted for almost half of the total cooperative output of these products in that year, while about two-thirds of this total was represented by the output of the 10 largest organizations. This concentration was somewhat greater in the packing of deciduous fruits than in seasonal vegetables. Among the associations that packed deciduous fruits, the 4 largest representing not quite one-fifth of the number canning these fruits contributed well over two-thirds or 70 percent of the cooperative total, and 7 , or one-third of the number, canned nearly nine-tenths of this total. In seasonal vegetable canning, 16 of the 47 associations or slightly more than one-third, accounted for four-fifths of the total packed by farmer cooperatives.

With respect to output of individual products one association canned most of the cooperative pack of apples, while two associations accounted for nearly all the apricots, and two well over four-fifths of all the peaches canned by cooperatives. One organization canned more than 80 percent of all the cooperatively packed beets, two associations more than 70 percent of all the spinach, while three provided about 70 percent of the total cooperative output of canned green snap beans, the leading vegetable handled by cooperative canners.

Citrus canning by cooperatives, consisting almost entirely of single strength juice, is likewise dominated by a few associations. During the 1943-44 season, 3 of the 13 cooperatives canning this product turned out well over half of the cooperative total, while 5 canned about threefourths. The output of these 5 associations represented about one-fifth 
Table 2. - Number of cooperative associations packing principal seasonal vegetables and fruits, 1939, 1943, and 1944

\begin{tabular}{|c|c|c|c|c|c|c|c|}
\hline \multirow[t]{2}{*}{ Vegetable } & \multicolumn{3}{|c|}{$\begin{array}{l}\text { Number of } \\
\text { cooperative } \\
\text { associations } \\
\text { packing }\end{array}$} & \multirow[t]{2}{*}{ Fruit } & \multicolumn{3}{|c|}{$\begin{array}{l}\text { Number of } \\
\text { cooperative } \\
\text { associations } \\
\text { packing }\end{array}$} \\
\hline & 1939 & 1943 & 1944 & & 1939 & 1943 & 1944 \\
\hline Tomatoes............. & 43 & 29 & 23 & Cherries............ & 17 & 9 & 13 \\
\hline Corn, sweet......... & 16 & 14 & 16 & Peaches............ & 12 & 7 & 10 \\
\hline Beans, snap green... & 17 & 11 & 13 & Berries............. & (b) & 10 & 8 \\
\hline Peas, green..... & 6 & 8 & 10 & Pears................ & 13 & 8 & 8 \\
\hline 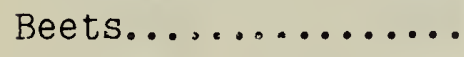 & 4 & 5 & 4 & Apricots............. & 7 & 2 & 3 \\
\hline Spinach............ & 8 & 4 & 4 & Apples.............. & 9 & 2 & 1 \\
\hline Tomato juice... & 1 & 7 & 8 & Grapefrult julce... & 6 & \multirow{4}{*}{\multicolumn{2}{|c|}{$\begin{array}{l}{ }^{b} 12 \\
b \\
{ }^{b} \\
{ }^{b} 9 \\
{ }^{b} 8\end{array}$}} \\
\hline Other tomato & & & & Grapefrult sections. & 2 & & \\
\hline products... & (a) & 5 & 6 & Orange juice........ & (a) & & \\
\hline & & & & Blended citrus juice & (a) & & \\
\hline
\end{tabular}

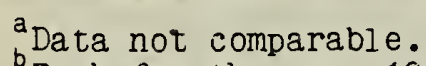

Pack for the year 1943-44.

Source of data: For 1939, Fogelberg, N., and Leith, G. W., "Cooperative Canning of Fruits and Vegetables, "F. C. A. Bul. 47, p. 18. For 1943 and 1944, reports to Federal agencies on operations during those years. The number reporting in the last 2 years is slightly less than the total number in business during those years, since a lew of the small canneries failed to submit reports.

of the total production of the industry, including both privately operated organizations and cooperatives.

As contrasted with the number of large multi-product cooperatives on the Pacific coast, the small one-product cooperative canneries are more characteristic of Virginia and the Middle West.

\section{WHAT COOPERATIVES PACK}

The number of associations engaged in packing each of the more important seasonal vegetables and fruits in 1939, 1943, and 1944 are given in table 2. The same number of associations canning a certain product in 1943 and 1944 does not necessarily mean that identical associations are represented in both years. Changes in products canned from year to year may be the result of weather or price and market conditions.

\section{SEASONAL VEGETABLES}

Although only 11 cooperatives canned green snap beans in 1943 and 13 in 1944, their output constituted about one-third of the total.cooperative pack of seasonal vegetables in 1943 and more than one-fourth of this pack in 1944 (table 3 ). The next most important vegetable in cooperative canning in those 2 years was sweet corn. The volume of sweet corn canned was close to one-fifth of the total cooperative vegetable pack in each year.

Table 3 shows the relative size of the pack of the principal seasonal vegetables canned by cooperatives in the total cooperative and in the 
Table 3. - Percent of cooperative pack and of total United States pack of principal seasonal vegetables accounted for by each specified vegetable, 1943 and 1944

(Case basis: 24 No. 2 cans)

\begin{tabular}{|c|c|c|c|c|}
\hline \multirow{2}{*}{ Vegetable } & \multicolumn{2}{|c|}{ Cooperative pack } & \multicolumn{2}{|c|}{ United states pack } \\
\hline & 1943 & 1944 & 1943 & 1944 \\
\hline & \multicolumn{4}{|c|}{ Percent } \\
\hline Beans, green snap.......... & 33.1 & 28.3 & a 16.5 & a 14.7 \\
\hline 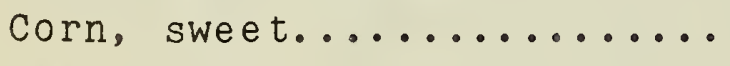 & $19 \cdot 4$ & $18 \cdot 6$ & 20.8 & $20 \cdot 0$ \\
\hline Peas, green............... & 11.3 & $14 \cdot 6$ & 25.9 & $25 \cdot 2$ \\
\hline 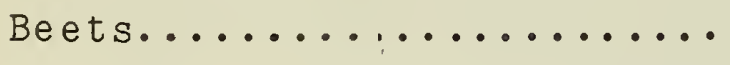 & 14.0 & $13 \cdot 6$ & 5.1 & $7 \cdot 1$ \\
\hline 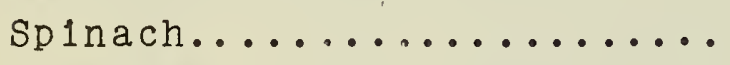 & 6.3 & 7.5 & 5.5 & 7.2 \\
\hline 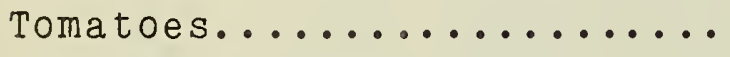 & 8.3 & 6.5 & 21.1 & 19.9 \\
\hline 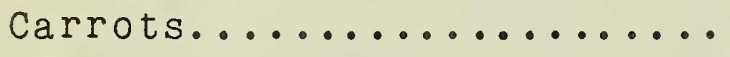 & 4.7 & 6.3 & 2.2 & 2.4 \\
\hline Squash and pumpkin........ & 2.3 & $3 \cdot 6$ & 1.5 & $2 \cdot 2$ \\
\hline Beans, green $11 \mathrm{ma} . . . . . .$. & 0.6 & 1.0 & 1.4 & 1.3 \\
\hline 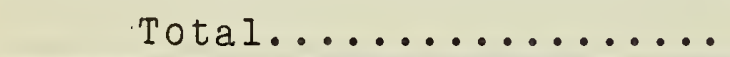 & 100.0 & 100.0 & 100.0 & 100.0 \\
\hline
\end{tabular}

ancludes wax beans.

Source of data: Original reports to the Farm Credit Administration and other Federal agencies.

total United States pack. Green snap beans were a much less important product in the national than in the cooperative aggregate. This vegetable accounted for only about half as large a part of the national as of the cooperative total. Canned sweet corn, on the other hand, had. about the same relative position in the cooperative as in the national total. In each case it constituted about one-fifth of the total. Peas, which provided about one-fourth of the pack of the country as a whole, were only about $11^{\prime}$ percent and 15 percent of the cooperative totals in 1943 and 1944, respectively.

Tomatoes have been canned for many years by more farmer cooperatives than any other vegetable or fruit. Many of these canneries are small and operate exclusively to can tomatoes. Most of the associations canning tomatoes that also can other products pack only one other item, generally snap beans, peaches, or cherries.

Tomatoes accounted for only 8 percent of the total seasonal vegetables packed by cooperatives in 1943 and 6.5 percent in 1944. In the national total, however, tomatoes accounted for about 20 percent.

Among the "big four" vegetables, peas, corn, tomatoes, and snap beans, the estimated output of cooperative canneries totaled about $3 \frac{1}{2}$ million cases in 1943, or approximately 3 percent of the national pack of those vegetables in that year. In 1944, the cooperative pack was slightly larger and the whole country's total somewhat less, so that cooperatives furnished almost 4 percent of the national total. The place of the cooperative pack of each of the four vegetables in the national total for each of these 2 years is shown on chart 1 . 


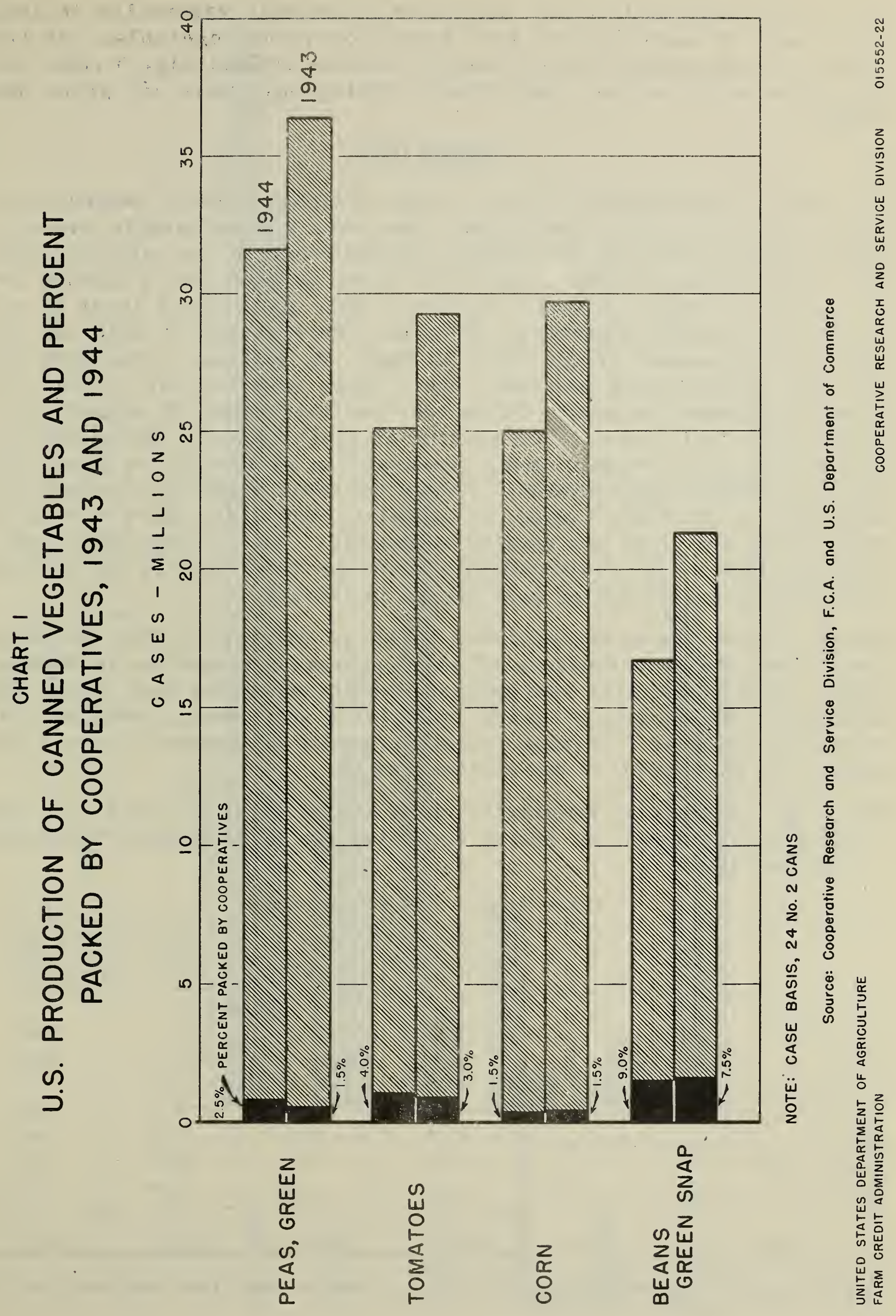


of the 33 cooperatives that canned only seasonal vegetables in 1944, there were 20 associations that packed only one vegetable. of this number, 13 represented those canning tomatoes exclusively, $\mathbf{5}$ those canning corn only, and one each those canning only peas and green snap beans.

\section{DEGOUNOS FRUITS}

The relative importance of the several deciduous fruits canned varies appreciably with crop conditions. But over a considerable number of years peaches have been the leading canned fruit in the national total. For cooperatives, however, pears were about as important a canning crop as peaches in 1943 and 1944. Together, they constituted about 70 percent of the total cooperative deciduous fruit packed in 1943 and were more than 50 percent of the total in 1944. As 1943 was a poor crop year for both cherries and apricots, their packs were low but in 1944, the former accounted for nearly 18 percent and the latter 16 percent of the cooperative fruit total. The packing of fruit cocktail and other mixed fruits has not developed among cooperatives as rapidly as among many private canning.organizations. Nearly the whole quantity, whether cooperatively or privately canned, is packed in California where most of the fruits used are grown and readily accessible. The relative positions in 1943 and 1944 of the principal fruits in the total cooperative pack and in the total United States pack appear in table 4.

Chart 2 shows the total national packs of these principal deciduous fruits and the contributions of the cooperative canneries in 1943 and 1944. From a relative standpoint, the cooperatives made their best showing in the canning of pears and berries and, during 1944, of cherries. In spite of the large cooperative pack of peaches, it is a comparatively small part of the national total.

Table 4. - Percent of cooperative pack and of total United States pack of principal deciduous fruits accounted for by each specified fruit, 1943 and 1944

(Case basis: 24 No. 2 cans)

\begin{tabular}{|c|c|c|c|c|}
\hline \multirow{2}{*}{ Fruit } & \multicolumn{2}{|c|}{ Cooperative pack } & \multicolumn{2}{|c|}{ United States pack } \\
\hline & 1943 & 1944 & 1943 & 1944 \\
\hline & \multicolumn{4}{|c|}{ Percent } \\
\hline Peaches................. & 34.5 & 27.0 & 41.9 & 34.5 \\
\hline 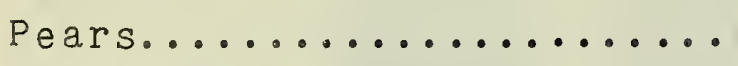 & 35.9 & 23.7 & 17.0 & 10.6 \\
\hline 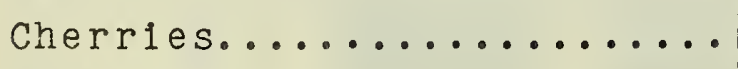 & 5.0 & 17.6 & 4.7 & 8.4 \\
\hline Apricots $\ldots \ldots \ldots \ldots \ldots$ & 4.0 & 16.0 & 4.7 & $19 \cdot 7$ \\
\hline 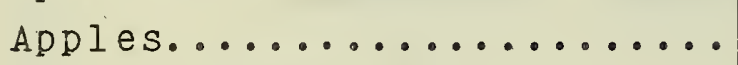 & 7.7 & 5.1 & $7 \cdot 2$ & 9.6 \\
\hline 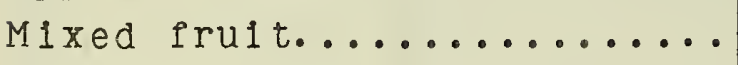 & 5.9 & 7.7 & 20.9 & 16.0 \\
\hline 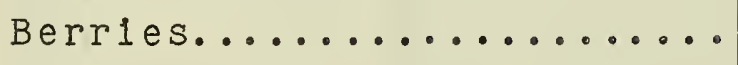 & 7.0 & 2.9 & 3.6 & 1.2 \\
\hline 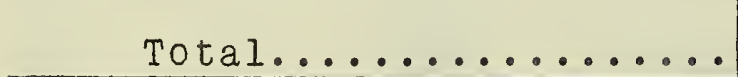 & 100.0 & 100.0 & 100.0 & 100.0 \\
\hline
\end{tabular}

Source of data: Cooperative Research and Service Division, Farm Credit Administration, and United States Department of Commerce. 


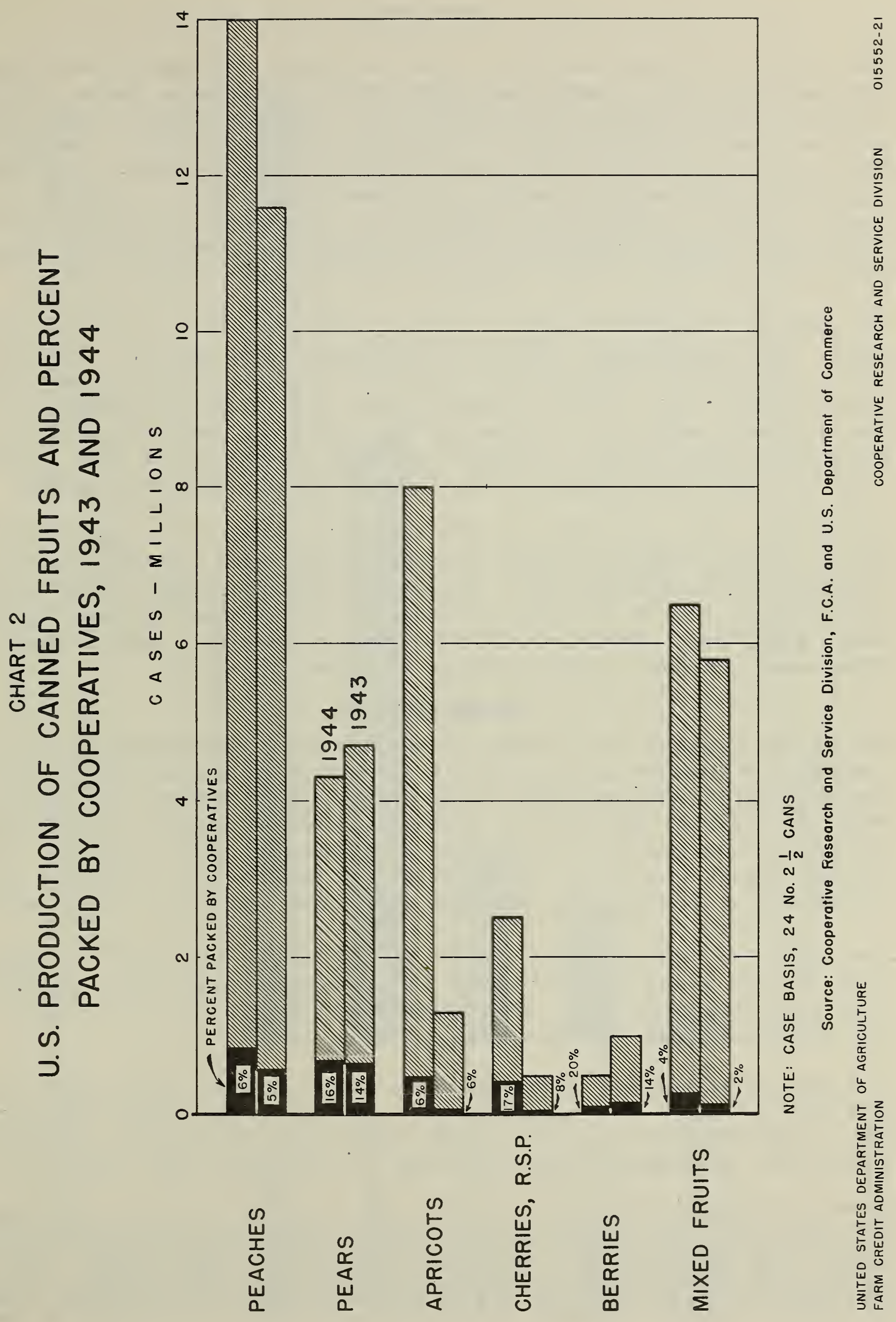


The position of cooperatives is relatively much stronger in the citrus canning field than in any other broad fruit or vegetable field. In the 1943-44 season cooperatives produced well over one-fourth of the total national pack of citrus juices, accounting for one-fourth of the grapefruit juice, one-third of the single-strength orange juice, and almost one-third of the national output of blended juice. Only a comparatively small output of grapefruit segments was reported by cooperatives, amounting to about 1 percent of the national total of 1 million cases. This was due in part to war conditions, particularly labor scarcity.

The 1943-44 cooperative pack of citrus juices is worthy of special comment. The cooperatives' output of grapefruit juice was more than twice the total quantity canned by all processors in the country in any year before 1936, their single-strength orange juice pack was almost twice the national output in any year before 1939, and their blended juice pack more than 3 times the yearly national output up to 1938. Thus, they have fully kept pace with the industry in its phenomenal growth.

Grapefruit juice accounted for more than half of the total reported volume of citrus products canned by cooperatives, with a 1943-44 pack estimated at 6.6 million cases. The single-strength orange juice output was slightly less than 3 million cases and the blended juices slightly under 2 million. Total United States production and estimated cooperative output of these citrus products is shown in chart 3 .

\section{OUTLOOK FOR FUTURE}

The farmer cooperatives included in the foregoing discussion have made a notable contribution to the nation's war effort in the canning of fruits and vegetables. Some 33 plants of 28 organizations received the achievement "A" award of the War Food Administration for a year's ou'tstanding performance in quantity and quality of production and cooperation with the Government in the war effort. Eleven of these cooperatives were also recipients of the "Star" award for an additional year of such performance.

Now, with the war over, what are the prospects for the future? Cooperative canners along with others in the canning industry are confronted with more diverse problems and greater uncertainties than ever before in the history of this industry.

The canning of seasonal vegetables is a hazardous undertaking with a resulting high mortality rate that has been shared by cooperative packers. These hazards are particularly pronounced among small, one-plant operators. ${ }^{5}$ Organizations that are able to distribute their risks over a

\footnotetext{
${ }^{5}$ There are additional hazards in the cooperative form or organization, and it is significant that one of the two major reasons for discontinuance of cooperatives is insufficient volume. The average annual rate of discontinuance of fruit and vegetable cooperatives was among the highest of the commodity groups of cooperatives during the 20-year period, 1920-39. It is not known, however, whether the mortality was higher or lower amorig cooperatives having canneries than those confining their operations to fresh fruits and vegetables. See Cochrane, W. W., and Elsworth, R.H., "Farmers' Cooperative Discontinuances 1875-1939." F.C.A. Misc. Rpt: 65, 1943.
} 


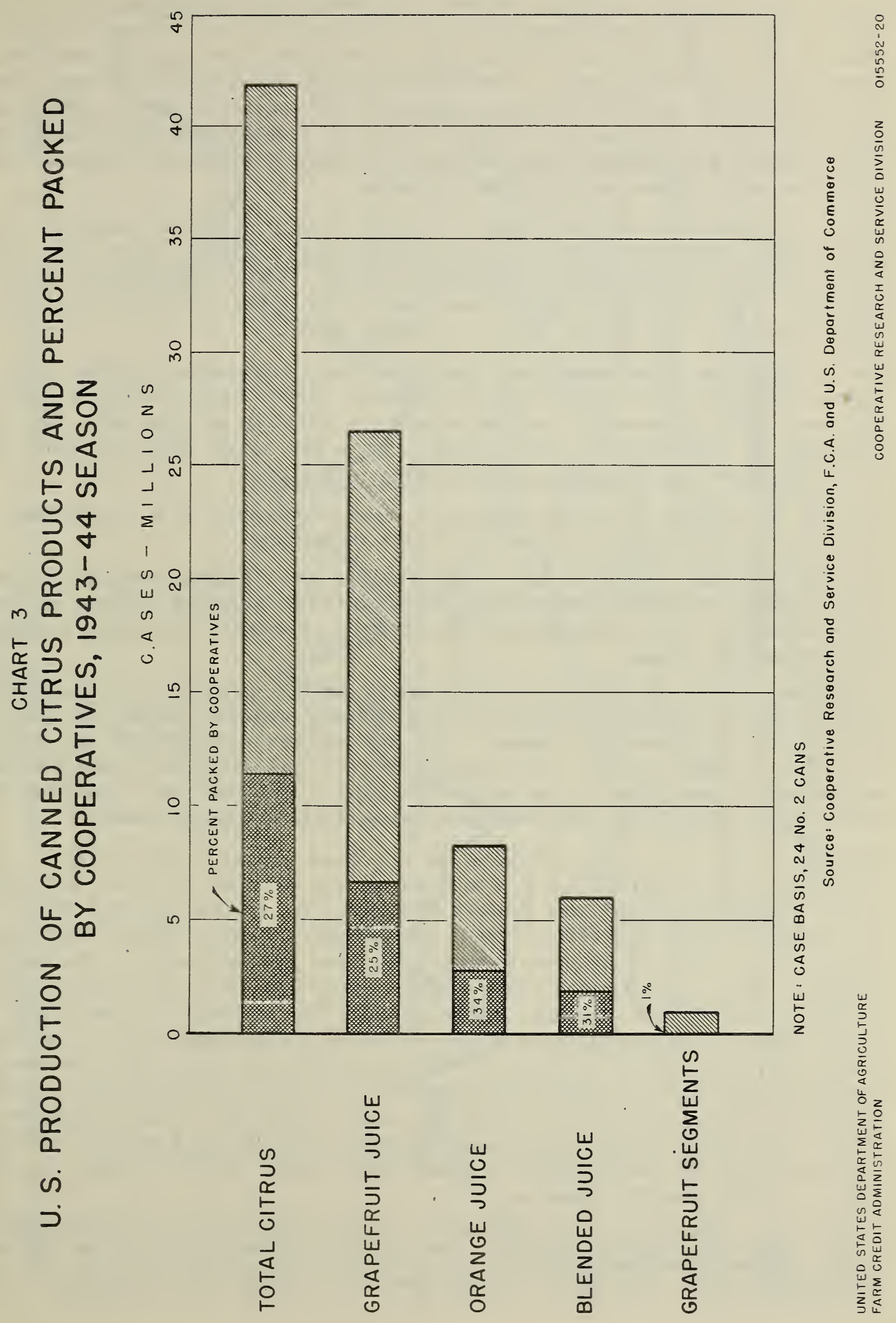


number of plants or among a number of comodities are better fortified against losses arising from local crop failures or other adverse developments than those primarily or solely dependent upon one or two crops grown in a restricted area. This circumstance may account in large part for the present and increasingly concentrated character of the fruit and vegetable canning industry, which is becoming dominated by a few large Nation-wide corporations that pack many different products in plants located in most of the large producing areas.

Farmer cooperatives in contrast to the privately operated canners, even some that are outstanding in the cooperative field, are typically smaller, more localized, and many confine their operations to one product. ${ }^{\circ}$ Hence, most cooperatives have less opportunity for spreading risks geographically or in terms of products.

Furthermore, as this means that most fruit and vegetable canning cooperatives lack extensive capital resources, their work in the field of technological research - so important in quality maintenance and improvement - is limited. Nor, except for a few large associations, can they undertake the extensive advertising campaigns.

Briefly then, many of the cooperative canneries start with a handicap in their production operations and in their marketing.

At this writing, however, most cooperatives are in good financial position. They have benefited along with private canners in the wartime opportunities for exceptionally profitable operation from heavy demand and favorable prices.

Likewise, they should be able to share in the prospective continued growth of the canning industry if the pre-war upward trends can be projected into the postwar years. The per capita consumption of canned fruits and vegetables in the United states has increased appreciably since before World War I, as shown in table 5 and chart 4. The peak was attained in 1941, the last year preceding wartime restrictions.

However, there are some prophets in the food industry who forecast inroads into the canning field from alternative methods of fruit and vegetable preparation that may result in a decline in the present level of consumption of canned fruits and vegetables. Frozen fruits and vegetables are likely to become the most serious competitors of the canned products and a few frozen fruits and vegetables have already attained consumer preference in many households. The aggregate production of frozen fruits and vegetables is as yet relatively small but is increasing rapidly and with improved production technique and, with extensive expansion expected in refrigeration facilities for transporting, storing, and retailing, these frozen foods may gain widespread consumer approval. A number of cooperative organizations have been in the forefront of this new food industry development and some have added quick-freezing facilities to their canning plants.?

${ }^{6}$ Accordingly, canning costs per unit of output of cooperatives tend to be higher because so large a proportion of the associations can only one or two commodities which must thus bear the full burden of overhead costs.

7 See Gessner, Anne L., "Cooperative Possibilities in Freezing Fruits and Vegetables." F.C.A. MIsc. Rpt. 84, 1945. 


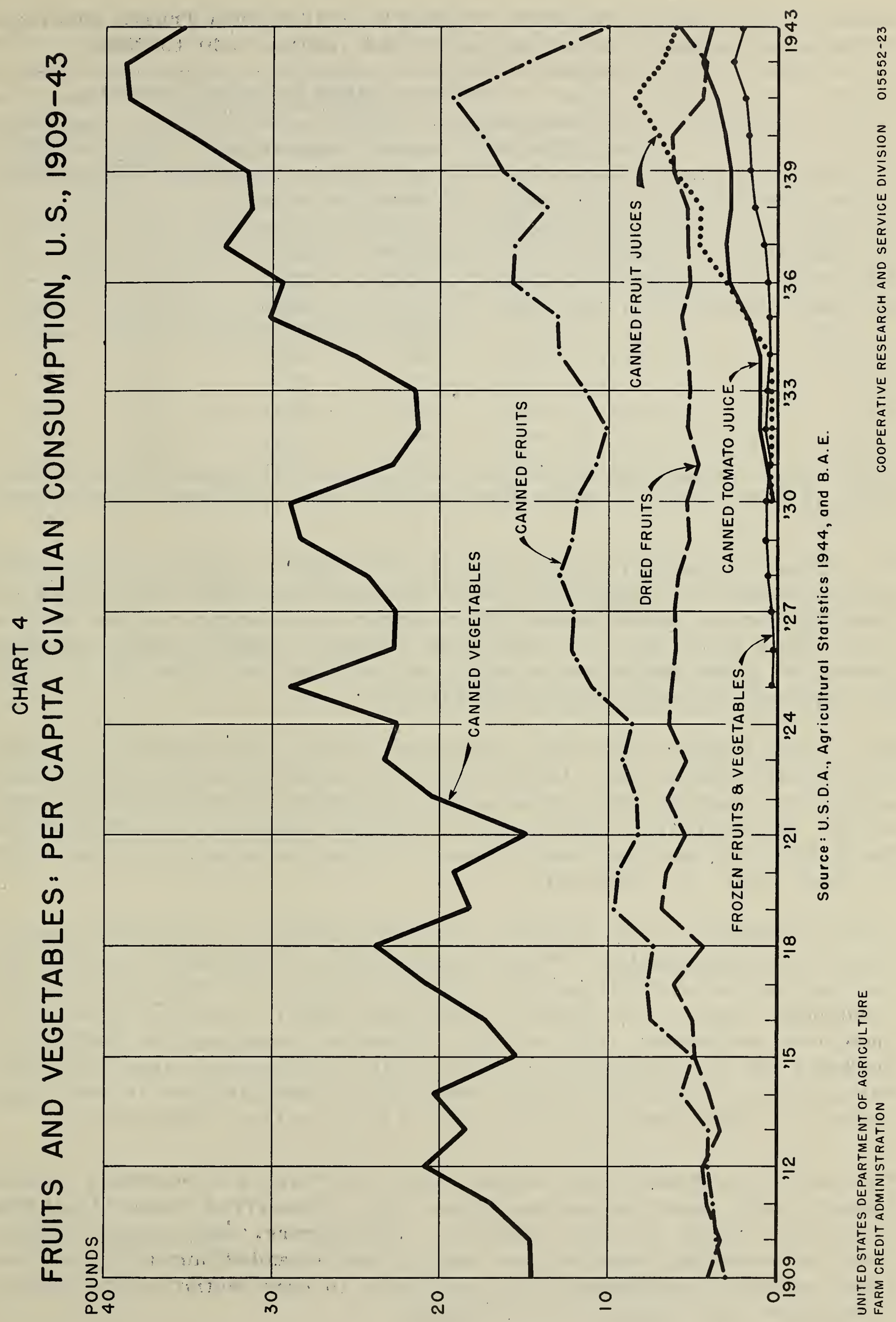


Table 3. - Per capita civilian consumption of canned fruits and vegetables in pounds by 5-year averages, and yearly, 1940 to 1943

\begin{tabular}{|c|c|c|c|c|c|}
\hline \multirow{2}{*}{ Years } & \multicolumn{5}{|c|}{$\begin{array}{c}\text { Pounds cf canned fruits and vegetables } \\
\text { consumed per capita }\end{array}$} \\
\hline & Total & Fruits & Vegetabies & $\begin{array}{l}\text { Fruit } \\
\text { juices }\end{array}$ & $\begin{array}{l}\text { Tomato } \\
\text { juice }\end{array}$ \\
\hline $1910-14 \ldots \ldots \ldots \ldots \ldots$ & $22 \cdot 4$ & $4 \cdot 2$ & $18 \cdot 2$ & - & - \\
\hline $1915-19 \ldots \ldots \ldots \ldots \ldots$ & 26.6 & $7 \cdot 4$ & $19 \cdot 2$ & - & - \\
\hline $1920-24 \ldots \ldots \ldots \ldots \ldots$ & 28.8 & 8.8 & 20.0 & - & - \\
\hline $19 \approx 5-29 \ldots \ldots \ldots \ldots$ & 37.6 & $12 \cdot 1$ & 25.5 & - & - \\
\hline $1930-34 \ldots \ldots \ldots \ldots \ldots$ & 36.7 & 11.5 & 24.0 & 0.4 & 0.8 \\
\hline $1935-39 \ldots \ldots \ldots \ldots$ & 52.6 & 14.9 & 31.0 & $4 \cdot 1$ & 2.6 \\
\hline $1940-43 \ldots \ldots \ldots \ldots \ldots$ & 63.2 & 15.4 & 36.9 & 7.1 & 3.8 \\
\hline $1940 \ldots \ldots \ldots \ldots \ldots \ldots$ & 62.7 & 17.5 & 35.0 & $7 \cdot 1$ & $3 \cdot 1$ \\
\hline $1941 \ldots \ldots \ldots \ldots \ldots \ldots$ & 70.0 & $19 \cdot 3$ & $38 \cdot 6$ & 8.5 & 3.6 \\
\hline $1942 \ldots \ldots \ldots \ldots \ldots \ldots \ldots$ & 64.8 & 14.9 & 38.7 & 6.8 & $4 \cdot 4$ \\
\hline $1943 \ldots \ldots \ldots \ldots \ldots \ldots$ & $55 \cdot 2$ & 10.0 & 35.3 & 6.0 & 3.9 \\
\hline
\end{tabular}

Scurce of data: U. S. D. A. Agricultural Statistics, 1944, and Bureau of Agriculturai Economics.

The threat of postwar competition to the canning industry from dehydrated products is undoubtedly much less serious, since the factors accounting for the rapid expansion of dehydration during the war will be of far less importance in a peacetime economy. However, some continued denand for a few dehydrated products may be expected, especially if they are improved by better processing methods.

Air transportation will also undoubtedly affect the market for canned fruits and vegetables. It will almost certainly offer fast freight service for quality fresh fruits and vegetables at progressively lower costs. This service, together with probable expansion in refrigeration facilities for rail and truck lines, is bound to stimulate consumption of fresh fruits and vegetahles.

Further impetus to the marketing of fresh produce is promised by developments in prepackaging. These packages will be designed to get fruits and vegetables to the housewife in more attractive form and in better condition. Much of the labor of preparing them for cooking already will have been performed. The use of transparent wrappings in family-size packages and the expansion of retail store refrigerated space may ultimately revolutionize the retail handling of fresh produce in most large renters of urban population and also in many smaller communities.

The factors outlined above suggest that the fruit and vegetable canning industry will face the postwar years with intensified competition from alternative forms of their products. Furthermore, many persons believe that the producing capacity for canning was expanded during the war beyond peacetime requirements for some years to come so that intra-industry competition will likewise be increased. 
In making their readjustments to postwar conditions, therefore, cooperative canners like most other industrial groups are faced as never before by many and diverse problems. Successful operation will require intelligent and progressive management at all times in each phase of their operations. In particular, farmer cooperatives will need to give careful attention to quality maintenance and improvement, to technological developments affecting their industry; to changing marketing methods, and to shifts in consumer preferences. They can be strengthened appreciably by well-planned programs of marketing and advertising and by other means adopted to bring them closer to consumers. If adequate consideration is given to these factors, cooperative canners should be able to hold their own in competition with the large nationally organized private food-processing corporations. 
U. S. DEPARTMENT OF AGRICULTURE FARM CREDIT ADMINISTRATION

KANSAS CITY 8, MO.

OFFICIAL BUSINESS

FORM P50-4/46-1,330

PERMIT NO. 1001
PENALTY FOR PRIVATE USE TO AVC PAYMENT OF POSTAGE. $\$ 300$ 